Ann Biomed Eng. 2014 February ; 42(2): 323-337. doi:10.1007/s10439-013-0859-6.

\title{
Biomaterials for Tissue Engineering
}

\author{
Esther J. Lee ${ }^{1}$, F. Kurtis Kasper ${ }^{1}$, and Antonios G. Mikos ${ }^{1,2}$ \\ ${ }^{1}$ Department of Bioengineering, Rice University, P.O. Box 1892, MS 142, Houston, TX \\ 77251-1892, USA \\ ${ }^{2}$ Department of Chemical and Biomolecular Engineering, Rice University, P.O. Box 1892, MS \\ 362, Houston, TX 77251-1892, USA
}

\begin{abstract}
Biomaterials serve as an integral component of tissue engineering. They are designed to provide architectural framework reminiscent of native extracellular matrix in order to encourage cell growth and eventual tissue regeneration. Bone and cartilage represent two distinct tissues with varying compositional and mechanical properties. Despite these differences, both meet at the osteochondral interface. This article presents an overview of current biomaterials employed in bone and cartilage applications, discusses some design considerations, and alludes to future prospects within this field of research.
\end{abstract}

\section{Key Terms \\ Bone; Cartilage; Osteochondral; Scaffolds}

\section{Introduction}

Tissue engineering is an interdisciplinary field dedicated to the regeneration of functional human tissues. Despite the body having intrinsic self-healing properties, the extent of repair varies amongst different tissues, and may also be undermined by the severity of injury or disease. ${ }^{48}$ The classic paradigm relies on a combination of biomaterial scaffolds, cells, and bioactive molecules to orchestrate tissue formation and integration within the host environment. An important avenue of tissue engineering is the development of biomaterials that can promote regenerative processes by effectively transporting cell populations and therapeutic agents, as well as providing structural scaffolding that confer sufficient mechanical properties to tissues. Moreover, the biomaterial should ideally degrade at a comparable rate to growth of new tissue at the site of implantation.

Among a multitude of applications, the musculoskeletal tissues of bone and cartilage have garnered substantial interest from researchers. ${ }^{35}$ Defects associated with these regions are quite prevalent in society and contribute to diminished quality of life; for example, roughly 450,000 bone grafts and 250,000 knee arthroplasties are performed in the United States annually. ${ }^{49}$ More recently, the focus has shifted toward seamlessly resolving the interface between bone and cartilage. Successful integration between these two contrasting tissue types remains a significant challenge.

Address Correspondence to Professor Antonios G. Mikos, Department of Bioengineering, Rice University, P.O. Box 1892, MS 142, Houston, TX 77251-1892, mikos@ rice.edu, Telephone: +1-713-348-5355, Fax: +1-713-348-4244.

Conflicts of Interest

No benefits in any form have been or will be received from a commercial party related directly or indirectly to the subject of this manuscript. 
Over the years, many different processing techniques and scaffold designs have been extensively explored, and led to notable improvements in the quality of tissue engineered constructs. This review commences with a brief overview of bone biology, followed by a discussion on recent advances in bone tissue engineering scaffolds, as well as accompanying design considerations. The focus then shifts to cartilage biology and highlights current work in osteochondral tissue engineering in addition to relevant design criteria. Finally, a short summary addresses the future outlook regarding the development of functional bone and cartilage replacements.

\section{Bone Tissue Engineering \\ Bone Structure, Function, and Pathology}

The organ structure consists of a marrow-filled center with bone tissue and periosteum enclosing it. The marrow sources cells of both osteogenic and hematopoietic lineages, in addition to providing a vascular network that ensures sufficient blood circulation throughout the organ. On a macroscopic scale, bone tissue can be classified into cortical (compact) and cancellous (trabecular) types; the former constitutes $80 \%$ of the skeletal structure and is appreciably denser than the latter - only $10 \%$ porous, as opposed to $50-90 \% .^{8,70}$ Microscopically, woven bone is an immature form characterized by a disorganized arrangement of collagen fibers, which eventually calcifies and matures into lamellar bone with spatially aligned collagen fibers. ${ }^{36}$

Matrix proteins including osteocalcin, bone sialoprotein (BSP), osteopontin, and osteonectin, proteoglycans such as small leucine-rich proteoglycan, aggrecan, hyaluronic acid (HAc) and heparan sulfate, and collagen fibers of mostly type I variety constitute the organic components ${ }^{26,47}$ Inorganic minerals of hydroxyapatite (HA) provide increased structural stiffness. ${ }^{28}$ Bone as a composite material thereby exhibits superb tensile strength and elasticity.

Monocyte-derived osteoclasts oversee bone resorption, in which the organic and inorganic phases are compartmentalized and degraded by acids and enzymes. ${ }^{88}$ Osteoblasts of mesenchymal origin subsequently migrate and populate these resorption sites, where they orchestrate the deposition of new bone matrix. ${ }^{37}$ Upon completion of this task, a number of osteoblasts undergo apoptosis, while the remainder integrate into the matrix as either osteocytes or bone lining cells that play an active role in sensing mechanical loads. ${ }^{63}$

The aforementioned structure and properties enable bone to facilitate movement, safeguard the body's organs and bone marrow, maintain a depository of minerals, and initiate a reparative response to fractures or other defects. ${ }^{12}$ Unfortunately, intrinsic healing may be limited in various cases of traumatic injury, disease, and tumor resection. Non-union fractures often arise in the event of insufficient vascularity, which prevents effective transport of nutrients via the blood vessels and thus prevents repair. ${ }^{64}$ Furthermore, the injured site can be unstable and succumb to excessive mechanical forces if not properly held in place. ${ }^{64}$ Secondary factors include lack of soft tissue coverage, bone loss, and infection. ${ }^{64}$

Large segmental bone defects have additional complications due to their size and weightbearing roles, while craniofacial defects take on many complex shapes that may be difficult to fill. ${ }^{25}$ Disruptions to normal processes, such as matrix synthesis, mineralization, and resorption, contribute to the development of bone-related diseases. For example, a decrease in the hormone estrogen leads to greater osteoclast numbers and increases bone resorption, which can lead to osteoporosis. ${ }^{17}$ Osteopetrosis is a rare congenital disorder characterized by hypofunctional osteoclasts that cause the formation of unusually dense bones that have greater susceptibility to fracture. ${ }^{55}$ Conversely, incomplete mineralization results in 
osteomalcia - a disease characterized by soft, weaker bones. ${ }^{55}$ These aforementioned issues prompt the need for developing scaffolds that can provide osteoconductive and osteoinductive cues to regenerate damaged bone tissue. The following section highlights a range of biomaterials that have recently been considered for such purposes.

\section{Scaffolds}

Calcium Phosphate Ceramics-Because calcium phosphate $(\mathrm{CaP})$ bioceramics are inherently stiff and slow degrading, they must often be combined with biodegradable polymers to yield better structures. The most commonly used $\mathrm{CaP}$ ceramics are hydroxyapatite (HA), $\beta$-tricalcium phosphate (TCP), and biphasic calcium phosphate (BCP) - a mixture of the previous two materials. By particulate leaching, Guo and colleagues fabricated calcium-deficient HA scaffolds of $54-81 \%$ porosity and noted that both in vitro and in vivo studies alluded to osteogenic outcomes. ${ }^{22}$ Bone regeneration was more pronounced in rabbit mandible defects when using scaffolds seeded with rabbit mesenchymal stem cells (rMSCs) versus acellular ones, but this difference diminished 2 to 4 weeks post-implantation. ${ }^{22}$ In another study, Teixeira et al. generated porous HA scaffolds that were also shown to promote bone formation following implantation into immunedeficient male mice. ${ }^{85}$ Bone morphogenetic protein (BMP)-2-loaded porous $\beta$-TCP scaffolds placed in rabbit femoral defects demonstrated 1.3 times more bone formation than their counterparts sans growth factor. ${ }^{80}$ As rapid prototyping strategies grow increasingly mainstream, they have been employed for greater design precision and scaffold production efficiency. For example, $\beta$-TCP scaffolds can be formed through a combination of microwave sintering and $3 \mathrm{D}$ printing techniques. ${ }^{74,84} \mathrm{Zhou}$ et al. pre-vascularized porous $\beta$ TCP scaffolds by co-culturing rMSCs and rMSC-derived endothelial cells and then implanted them into rabbit large segmental defects. ${ }^{103}$ Bone repair and integration with native tissue was noted 16 weeks later, demonstrating enhanced osteogenesis and vascularization. Human mesenchymal stem cells (hMSCs) were cultured on decellularized human umbilical vein endothelial cell-secreted extracellular matrix (ECM) coating a porous $\beta$-TCP scaffold. ${ }^{41}$ By using this, Kang et al. sought to incorporate bioactivity into a ceramicbased material for enhanced differentiation into bone cells. Increased expression of various osteogenic markers was further correlated to mitogen-activated protein kinase/extracellular signal-regulated kinase (MAPK/ERK) signaling pathway activation. ${ }^{41} \mathrm{Kim}$ et al. employed a gas foaming technique to produce BCP scaffolds consisting of 60:4 HA-to- $\beta$-TCP ratio with interconnected pores of $300-800 \mu \mathrm{m}$ and $75-85 \%$ porosity. ${ }^{43}$ Mouse mesenchymal stem cells (mMSCs) cultured for six days on this material were shown to differentiate into osteoblast-like cells. Additionally, bone formation following implantation into rat lower jawbones and tibias was observed. Though porous $\mathrm{CaP}$ materials have been primarily limited to small-sized defects, one study examined the effects of composition (HA, TCP, $\mathrm{BCP}$ ) and microstructural variations from sintering temperatures with the goal of determining suitable alternatives for bone autografts. ${ }^{100}$ Results elucidated from a sheep critical size bone defect noted TCP as most osteoinductive. ${ }^{100}$

Bioactive Glasses-Bioactive glass is structurally brittle, but has several desirable characteristics to capitalize upon: controllable degradation rate, ionic release with osteogenic potential, capacity to become HA-like material, and good bonding affinity to bone. ${ }^{67}$ Since the advent of silicate-based 45S5 glass (Bioglass ${ }^{\circledR}$ ), many other formulations have been devised and applied to bone tissue engineering research. ${ }^{40}$ Miguel et al. generated fibrous bioglass scaffolds that promoted the formation of a hydroxyapatite layer, as well as increased osteoblast activity. ${ }^{57}$ Furthermore, in vivo studies showed enhanced bone formation. $\mathrm{Wu}$ and coworkers designed cobalt ion-releasing mesoporous bioglass scaffolds to trigger low oxygen tension - a condition important for in vivo osteogenesis and angiogenesis. ${ }^{94}$ Greater proliferation and differentiation of hMSCs was noted, as well as 
positive effects on vascular endothelial growth factor (VEGF) secretion and hypoxiainducible factor (HIF)-1a and bone-related gene expression. ${ }^{94}$ More recently, cloth bandages made from woven bioglass were wrapped around rat tibial defects and resulted in some bone formation within the marrow cavity. ${ }^{58}$

Compared to their silicate-based counterparts, various borate bioglasses degrade more rapidly and therefore convert more readily into HA-like product. ${ }^{32}$ Borate bioglass pellets containing teicoplanin were implanted in a rabbit tibia osteomyelitis model, and not only sustained antibiotic release, but also facilitated a reparative effect on bone. ${ }^{101}$ In another study, boron ion release from mesoporous bioglass scaffolds increased osteoblast proliferation, in addition to collagen I (Col I) and runt-related transcription factor 2 (Runx2) gene upregulation. ${ }^{93}$ Incorporation of dexamethasone, an osteogenic drug, into this platform also enhanced alkaline phosphatase (ALP) activity and expression of bone-related genes. As borate bioglass is amenable to alteration, further fine-tuning its composition should improve its degradation rate to coincide with bone formation rate and also ensure that ions promoting this regenerative process can be released in a timely fashion. ${ }^{67}$

Metal-Based Materials-Porous metallic scaffolds have been investigated for bonerelated applications due to excellent physical properties and their ability to promote tissue ingrowth. The most commonly used materials in this category are titanium (Ti) and tantalum (Ta). Ti exhibits biocompatibility coupled with mechanical strength and good resistance to corrosion. ${ }^{78,82}$ Xue et al. generated Ti scaffolds ranging from $17-58 \%$ vol. porosity and with pore sizes to $800 \mu \mathrm{m} .{ }^{95}$ These structures displayed mechanical properties closer in consistency to bone, as well as enhancing osteoblast adhesion, proliferation and differentiation. ${ }^{95}$ Moreover, Ti has often been incorporated into alloys. A rat model of distal femur defect suggested that higher porosity of Ti6Al4V structures increased calcium deposition and consequently more bone tissue formation. ${ }^{4}$ Surface modification of $\mathrm{Ti}$ surfaces has been shown to increase osteoconductivity, as seen in work by Das et al. ${ }^{15}$ Through anodization, titanium dioxide $\left(\mathrm{TiO}_{2}\right)$ nanotubes were deposited onto porous $\mathrm{Ti}$ scaffolds, and these small scale features improved apatite-formation in simulated body fluid. $\mathrm{Li}$ and coworkers also evaluated various surface treatments of porous Ti6Ta4Sn, noting that a sol-gel HA coating yielded optimal adhesion of osteoblast-like cells. ${ }^{51}$

Despite greater cost and difficulty in manufacturing, Ta has recently garnered substantial attention because it possesses many of Ti's favorable qualities. Balla et al. fabricated Ta scaffolds ranging from $27-55 \%$ porosity that demonstrated superior osteoblast attachment, proliferation and differentiation capacity compared to their porous Ti counterparts. ${ }^{3}$ Unlike $\mathrm{Ti}$ and $\mathrm{Ta}$, magnesium $(\mathrm{Mg})$ has the additional characteristic of biodegradability. Witte and colleagues investigated the effects of porous Mg alloys in vivo and observed that bone formation and resorption accompanied scaffold degradation..$^{92}$ However, potential issues with corrosion and ionic leaching may curtail the use of these metal-based constructs.

Polymers-Polymers can be formed into versatile scaffold types, such as fibers and gels, which may be chemically functionalized to improve bioactivity and readily degrade within the body. Natural polymers commonly applied to bone-related applications include collagen, fibrin, alginate, silk, HAc, and chitosan. ${ }^{49}$ Mandal et al. fabricated silk scaffolds consisting of microfiber-reinforced bulk matrix, and the imparted stiffness enhanced the differentiation rate of hMSCs as well as upregulating various bone-related markers, such as osteopontin, BSP and ALP. ${ }^{53}$ In another study, osteoblasts cultured within strontium-crosslinked alginate hydrogels functionalized with arginine-glycine-aspartic acid (RGD) showed increased expression of Runx2, Col I, BSP, and ALP. ${ }^{66}$ Wang and Stegemann synthesized a chitosan hydrogel containing distributed collagen fibers; the former material promoted osteogenesis, while the latter was implicating in enhancing the proliferative capacity of hMSCs. ${ }^{90}$ 
Drawbacks associated with natural polymers, such as immunogenicity, variability depending on their source, and processing difficulty, have prompted the development of synthetic polymers with more tunable characteristics. ${ }^{49}$ Poly(a-esters) are frequently employed because they yield degradation products that can be naturally excreted, and certain devices based on these polymers have been regulated by the Food and Drug Administration (FDA). P24 - a BMP-2-related peptide - was functionalized on a poly(lactic-co-glycolic acid) (PLGA)/poly(ethylene glycol) (PEG)/aspartic acid (ASP) scaffold, with its controlled release shown to significantly influence rat MSC differentiation into osteoblasts in vitro and stimulate ectopic bone formation in vivo. ${ }^{52}$ Henslee et al. produced a scaffold comprised of a porous poly(propylene fumarate) (PPF) sleeve containing recombinant human BMP-2 (rhBMP-2) adsorbed PLGA microspheres that surrounded a solid PPF intramedullary rod. This increased mechanical stability in a rat segmental femoral defect; however, the porous PPF seemed to hinder regenerative cell migration into that region and prevented bone formation. ${ }^{27}$ Spicer et al. mixed polymethylmethacrylate (PMMA) bone cement with carboxymethylcellulose porogen to yield a porous space maintainer that polymerized in situ within a rabbit mandibular defect. ${ }^{81}$ Soft tissue healing was observed 12 weeks postimplantation, and inflammatory responses were not exacerbated relative to that of solid PMMA space maintainers.

Many bone tissue engineering approaches mimic intramembranous ossification, by which MSCs differentiate directly into osteoblasts. However, the endochondral route presents another alternative, whereby bone formation occurs via a cartilage template intermediate. To mimic the latter process, Yang et al. employed a wet electrospinning technique that collected PLGA/poly( $\varepsilon$-fcaprolactone) (PCL) in ethanol to form a looser fibrous network more conducive to cell ingrowth. ${ }^{96}$ Rat bone marrow-derived MSCs were chondrogenically preconditioned prior to in vivo implantation, resulting in bone regeneration and vessel infiltration. This approach provides a favorable alternative to cell pellet culture systems, since a 3D microenvironment is created without compromising mechanical strength. ${ }^{96}$

Finally, merging attributes from both natural and synthetic polymers may also prove beneficial. A poly(propylene carbonate) (PPC) scaffold provided structural augmentation to chitosan nanofibers within its macropores that contributed biomimetic cues for bone formation. ${ }^{102}$ In vitro studies demonstrated successful rMSC adhesion, proliferation, and differentiation, while subsequent in vivo work revealed accelerated osteogenesis and nearly complete bone regeneration within the defect by 16 weeks. ${ }^{102}$ Salgado et al. formulated an injectable PCL-sebacic acid gel, in which the latter component increased the former's generally slow rate of degradation. ${ }^{73}$ This biomaterial promoted MSC differentiation, evidenced by ALP activity and mineralization, and also rat tibial defects showed signs of bone growth. Additionally, Patel et al. generated porous PPF scaffolds with entrapped gelatin microparticles containing VEGF and BMP-2. Evaluation at 4-week and 12-week timepoints following implantation in a rat critical size cranial defect revealed significant bone regeneration and better integration with host tissue, suggesting the potential benefit of co-delivering the two growth factors. ${ }^{65}$ Young and colleagues further investigated the aforementioned system and discovered that decreasing BMP-2 concentration correlated to less bone formation. ${ }^{98}$ Moreover, simultaneous administration of VEGF and BMP-2 did not seem particularly advantageous over delivery of BMP-2 alone.

Composites-Composites are designed with the aim of leveraging key properties from at least two classes of materials. Natural or synthetic polymers are often combined with inorganic components, such as CaPs or bioglasses.

Miezawska et al. drew from the excellent mechanical strength and biodegradability of silk fibroin with the bioactivity of silica-based bioglass into composite films ${ }^{56} \mathrm{hMSCs}$ cultured 
on these scaffolds successfully proliferated and differentiated toward an osteogenic lineage, as deduced from increased bone-related marker expression and mineral deposition. PLGA microspheres have been combined with calcium phosphate cement to serve as porogens that accelerate degradation and bone growth. ${ }^{71}$ More recently, silica-based bioglass was incorporated to further improve the material's bioactivity, and results in critical-size rat femoral condyle defects indicated an enhanced osteogenic response. ${ }^{71}$ In another study, Yu et al. fabricated macrochanneled $\mathrm{CaP}$ scaffolds that maintained overall structural integrity, while the collagen hydrogel within its pores ensured cell distribution and retention. ${ }^{99}$ This system significantly influenced the role of rat MSCs in bone synthesis. ${ }^{99}$ With ease of clinical application in mind, Fu and colleagues designed a thermoresponsive hydrogel using PEG-PCL-PEG copolymer, collagen, and nano-HA filler. ${ }^{18}$ This was injected into rabbit calvarial bone defects, where it gelled based on the transition from room temperature to body temperature. X-ray and $\mu \mathrm{CT}$ showed that new bone completely filled the site by 20 weeks, and histological assessment confirmed the formation of mature cortical bone. ${ }^{18}$

Amosi et al. investigated the effects of combining osteoconductive $\beta$-TCP with selfassembling peptide hydrogels Pro-Asp-(Phe-Asp) $)_{5}$-Pro $\left(\mathrm{P}_{\mathrm{FD}}-5\right) .{ }^{1}$ Human fetal osteoblasts seeded onto these scaffolds proliferated and showed significantly increased ALP activity after 14 days of culture. Moreover, improved bone formation was observed following implantation in rat femoral defects. Based on the noted interactions between $\mathrm{P}_{\mathrm{FD}}-5$ 's ASP residues and calcium ions, the authors posited that the peptide hydrogel effectively sequesters these ions within the defect for use in bone regeneration, which might otherwise be dispersed away from the site by body fluids. ${ }^{1}$

Gerhardt et al. coated bioactive glass nanoparticles over decellularized trabecular bone to evaluate the potential for vascularization of tissue-engineered bone. ${ }^{20}$ In vitro findings revealed that fibroblasts secreted significantly more VEGF with nanoparticle incorporation. However, the bioactive coating seemingly had no enhanced effect compared to the uncoated nanoparticles upon implantation in a rat model.

Sitharaman et al. reinforced porous PPF scaffolds with ultra-short single-walled carbon nanotubes (US-SWNTs), which were subsequently implanted in rabbit femoral condyle defects and subcutaneous pockets to evaluate outcomes on both hard and soft tissue. ${ }^{79}$ Greater bone formation, fewer inflammatory cells, and appreciable organization of connective tissue were noted in US-SWNT/PPF scaffolds by 12 weeks. Likewise, Venkatesan and coworkers augmented chitosan scaffolds with functionalized multi-walled carbon nanotubes for improved mechanical support. ${ }^{89}$ MG-63 human osteosarcoma cells cultured on these composites demonstrated superior viability, proliferation, ALP activity, and mineralization compared to those on control scaffolds of only chitosan.

Design Considerations-Table 1 summarizes the various classes of biomaterials employed in bone tissue engineering strategies. There are evidently a number of parameters that influence the outcome of scaffold-mediated bone tissue regeneration. First, selected materials should exhibit biocompatibility and not elicit any adverse responses or degrade into toxic byproducts. ${ }^{30}$ The choice of processing technique also plays a key role in finetuning scaffold architecture to the desired application. ${ }^{44}$ Sufficient porosity is necessary to encourage cell infiltration and tissue ingrowth, with desirable pore sizes in the range of 200 to $400 \mu \mathrm{m} .{ }^{31}$ Pores should also be interconnected to allow for continuity in vascularization. ${ }^{45}$ At the same time, the scaffold's mechanical properties should not be compromised by the extent of porosity, since it needs to be sturdy enough to support the formation of functional bone. Appropriate bioactive signals such as inorganic minerals, growth factors and drugs may be coated onto the surface of or distributed throughout a biomaterial to provide osteoconductive and/or osteoinductive cues that can enhance bone 
growth and integration with the surrounding host tissue. ${ }^{9}$ Finally, scaffold degradation rates should be tailored to correspond with the bone regeneration timeframe in vivo.

In the next section, bone regeneration is considered along with cartilage, which opens up another set of unique challenges and additional design criteria. While these two tissues exhibit different properties, they must be fluidly resolved at their interface, as in the case of articulated joints.

\section{Osteochondral Tissue Engineering}

\section{Articular Cartilage Structure, Function, and Pathology}

Articular cartilage is an avascular, alymphatic, and aneural tissue that covers the surfaces of diarthrodial joints, with primary roles that include dissipating imposed loading stresses and facilitating low-friction movement. ${ }^{97}$ It consists of $60-85 \%$ water, an abundant ECM, and a sparse population of chondrocytes that play a vital role in cartilage development and maintenance. ${ }^{68}$

The ECM displays an assortment of collagen fibrils, predominantly type II, which endow articular cartilage with robust tensile strength, as well as sequester and retain proteoglycans - highly negative macromolecules that provide compression resistance. ${ }^{6}$ Articular cartilage possesses a distinct heterogeneous structure that can be classified into the following zones: superficial, middle and deep. ${ }^{87}$ The superficial zone contains collagen fibers parallel to the surface, in addition to chondrocytes with flattened morphology that are arranged horizontally. In the middle zone, collagen fibers are randomly oriented, and chondrocytes appear spherical and scattered. The deep zone has collagen fibers tangent to subchondral bone, along with larger chondrocytes organized in a vertical fashion. Finally, a tidemark separates the deep zone from the calcified cartilage region. The latter forms an interface with underlying subchondral bone, and this transitional region may generate substantial shear stresses due to the large discrepancy in tissue stiffness. ${ }^{13}$

Chondrocytes of mesenchymal origin comprise a miniscule fraction of articular cartilage volume, yet are chiefly responsible for synthesizing and assembling essential matrix components, such as collagens, proteoglycans, and glycoproteins. In turn, the ECM shields chondrocytes from mechanical forces imposed on the synovial joint during movement and promotes retention of their morphologic and phenotypic traits. ${ }^{7}$ Growth factors play an influential role in chondrocyte function. Members of the transforming growth factor (TGF)$\beta$ family enhance collagen and proteoglycan synthesis, as well as prevent matrix degradation and cell proliferation. ${ }^{7}$ Various BMPs are likewise implicated in promoting chondrogenesis. ${ }^{24}$

On the contrary, cytokines - for example, interleukins (ILs) and tumor necrosis factor (TNF)- $a$ - contribute to cartilage degeneration. ${ }^{29}$ Synovial joint structure may be disrupted by injury or disease. Aging increases the propensity for degeneration because of the chondrocytes' diminished ability to synthesize and maintain matrix, as well as their further lowered metabolic turnover rates. ${ }^{7}$ The ECM may also pose a barrier by hindering cell migration to the site of injury, while proteoglycans can limit cell adhesion. ${ }^{86}$

Articular cartilage lesions may be classified as partial-thickness or full-thickness. Partialthickness defects cannot heal spontaneously since they remain confined within the zonal layers of articular cartilage. ${ }^{33}$ Following traumatic injury, chondrocytes near the lesion proliferate and aggregate. The dense ECM impedes cells further away from the immediate region from contributing to reparation. ${ }^{91}$ Consequently, the interface between new tissue and native cartilage remains poorly resolved. Chondrocyte apoptosis generally occurs in 
these damaged regions. Moreover, fibroblasts supplant the tissue regeneration process by generating scar tissue instead of functional cartilage.

Exacerbated by external factors such as loading forces, articular cartilage degeneration may progress into full-thickness defects, which appear over the entire articular cartilage region and reach the marrow spaces of subchondral bone. ${ }^{5}$ These lesions are repaired via an extrinsic response mechanism. Several days post-trauma, blood from the bone marrow coagulates into a fibrin clot. ${ }^{34}$ MSCs migrate to the site of injury and undergo chondrogenic differentiation to stimulate type II collagen and proteoglycan production. ${ }^{29}$ This process is often undermined by inflammatory cells-mediated cytokine release that triggers angiogenic and fibrotic responses. ${ }^{29}$ Because fibroblasts have higher turnover rates than chondrocytes, the resulting cartilage generated at the lesion site tends to consist mostly of type I collagen with diminished proteoglycan content. ${ }^{54}$ The resulting fibrocartilage is thus more prone to subsequent degeneration. In light of these issues, a significant amount of research has been dedicated to restoring damaged articular cartilage, as well as developing strategies to promote tissue integration at the osteochondral interface.

\section{Scaffolds}

Single-Phase-For nearly two decades, single-phase scaffolds have been employed for osteochondral tissue engineering. These may be composed of either one or a combination of materials, provided that the distribution remains uniform throughout the scaffold.

Jeong et al. fabricated porous PCL scaffolds with chemically conjugated BMP-2 to evaluate potential for neocartilage generation, as well as endochondral ossification. ${ }^{38}$ Porcine chondrocytes cultured on scaffolds incorporated with BMP-2 exhibited greater cartilaginous matrix synthesis, as well as evidence of increased hypertrophy through upregulation of bone-specific markers osteopontin and type 10 collagen. However, in vivo results did not reveal enhanced bone formation compared to scaffolds sans BMP-2. In another study, Coburn et al. applied a wet electrospinning technique to generate loose fibrous networks of poly(vinyl alcohol)-methacrylate (PVA-MA) and chondroitin sulfate-methacrylate (CS-MA) in an ethanol bath. ${ }^{11}$ Goat MSCs seeded onto these scaffolds underwent chondrogenic differentiation in vitro, forming hyaline-like cartilage with increased elasticity, and moreover, the presence of CS resulted in higher type II collagen content. This in vitro observation held true following implantation of acellular fiber scaffolds into rat osteochondral defects made in the trochlear groove. Nanofibers with and without CS both facilitated proteoglycan deposition, and this amount was appreciably higher than in empty defects, though still not on par with that in native tissue. Histological evaluation showed early signs of zonal organization in articular cartilage, namely in cell orientation and a proteoglycan concentration gradient. ${ }^{11}$ Shah and coworkers developed self-assembling peptide amphiphile (PA) nanofibers containing TGF- $\beta 1$ binding domains that could facilitate localized, prolonged release of the growth factor. ${ }^{76}$ These scaffolds promoted the viability and chondrogenic differentiation of encapsulated human MSCs. When used in conjunction with microfracture in a rabbit chondral defect, PAs with TGF- $\beta 1$ binding epitopes exhibited higher matrix synthesis, and histological scoring revealed better quality articular cartilage than in cases with growth factor delivery or PA alone. Khanarian et al. incorporated HA particles into an agarose hydrogels and examined how their size and dose affected calcified cartilage formation typically observed at an osteochondral interface. ${ }^{42}$ Hypertrophic chondrocytes cultured within the scaffold responded optimally to $3.0 \mathrm{w} / \mathrm{v} \% \mathrm{HA}$ microparticles. In another study by Zhou and colleagues, hMSCs cultured on collagen and collagen/HA porous scaffolds demonstrated greater predisposition for the chondrogenic and osteogenic phenotype, respectively, as concluded via histology and assays of tissue-related markers. ${ }^{104}$ 
More recently, Sheehy et al. created a bilayered agarose hydrogel system with porcine chondrocytes and porcine MSCs comprising the chondral and osseous layers, respectively. ${ }^{77}$ This setup maintained chondrocyte phenotype, while preventing MSC hypertrophy. Additionally, endochondral ossification occurred exclusively in the MSC layer, which showed signs of mineralization following culture in hypertrophic medium containing $\beta$ glycerophosphate, as well as after subcutaneous implantation at a non-load bearing site in nude mice. ${ }^{77}$

Another approach entails presenting growth factors in a biomimetic fashion, as seen in work done by Re'em and colleagues, which involved affinity-binding of TGF- $\beta 1$ and BMP-4 to separate portions of a bilayered alginate hydrogel via alginate-sulfate ${ }^{69}$. Consequently, hMSCs responded to the prolonged expression of these growth factors and could more effectively differentiate into the desired chondrogenic and osteogenic phenotypes than in scaffolds containing unbound counterparts. To more closely replicate the collagen network in the ECM, Levorson et al. generated electrospun scaffolds consisting of PCL microfibers and fibrin nanofibers through a dual extrusion approach with a rotating mandrel, which merged the benefits of larger pore sizes and better cellular response to nanoscale diameters. ${ }^{50}$ This combination of fibers exhibited a favorable influence on glycosaminoglycan (GAG) production under serum-free conditions, and may be useful for engineering cartilage. Finally, Schwarz and coworkers highlighted their processing techniques for cartilage decellularization to obtain ECM-based scaffolds. ${ }^{75}$ Preliminary results suggested that these matrices were not cytotoxic and in fact suitable for both cell proliferation and cartilage matrix synthesis. ${ }^{75}$

Biphasic and Multiphasic-Compared to single-phase scaffolds, biphasic and multiphasic scaffolds may better recapitulate the structural differences in articular cartilage and subchondral bone. Jiang et al. sought to mimic not only an environment conducive for the individual tissues but also the calcified cartilage interface between them, with agarose hydrogel seeded with chondrocytes constituting the cartilage phase, sintered PLGA-45S5 Bioglass microparticles containing osteoblasts representing the bone layer, and a mixture of agarose/PLGA-Bioglass with chondrocytes forming the interfacial boundary. ${ }^{39}$ Based on in vitro findings, the multiphasic regions remained well integrated and maintained their respective cell populations' phenotypes. Matrix abundant in proteoglycans was observed in the cartilage region, while mineralization was demonstrated in the bone phase. ${ }^{39}$ However, the authors noted that mechanical properties warranted further improvement. In another study, Chen and coworkers incorporated plasmid DNA encoding for TGF- $\beta 1$ and BMP-2 into porous scaffolds of chitosan/gelatin and HA/chitosan/gelatin respectively to spatially regulate osteochondral tissue regeneration. ${ }^{10}$ rMSCs were pre-cultured on these layers for one week before being joined together with fibrin glue and maintained in vitro for another week. The resulting bilayered scaffold was subsequently implanted into rabbit osteochondral defects in the patellar groove, where rMSCs in each layer were shown to form cartilage-like and bone-like tissue that integrated fairly well with the surrounding native tissue. Bal and colleagues designed bilayered constructs of rMSC-seeded PEG hydrogel and acellular porous Ta metal, which were then implanted into rabbit osteochondral defects for 12 weeks. ${ }^{2}$ Ta promoted subchondral bone regeneration and integration, and additionally contributed to formation of tissue reminiscent of hyaline cartilage. ${ }^{2}$ There may be concerns, however, regarding the metal's non-biodegradability and the possibility of releasing byproducts associated with it.

To produce a bilayered scaffold of interconnected pores, Galperin et al. applied a spheretemplating fabrication method, in which PMMA microparticles of $200 \mu \mathrm{m}$ and $38 \mu \mathrm{m}$ serving as porogens were entrapped within a poly(2-hydroxyethyl methacrylate) (PHEMA) hydrogel to constitute the respective articular cartilage and subchondral bone layers. ${ }^{19}$ Additionally, 
HAc was functionalized to PHEMA to promote chondrogenesis of hMSC-derived chondrocytes, while HA was coated onto PMMA nanoparticles as a bioactive cue for osteogenesis of hMSCs. This osteochondral scaffold fostered favorable cell responses and ECM synthesis. Getgood et al. compared the osteochondral repair potential of two commercially available biphasic scaffolds, Chondromimetic ${ }^{\mathrm{TM}}$ (collagen-GAG-CaP) and Truefit $^{\text {TM }}$ (PLGA/poly(glycolic acid) (PGA)/calcium sulfate), in the medial femoral condyle and lateral trochlear sulchus of goats. ${ }^{21}$ The mechanical properties of collagen-GAG-CaP notably improved over the course of 13 weeks. Moreover, this scaffold generated primarily hyaline-like cartilage as opposed to fibrocartilage in $75 \%$ of defects at 26 weeks, compared to the $50 \%$ outcome observed with PLGA/PGA/calcium sulfate. ${ }^{21}$

Gradient-With increasing attention on the cartilage-bone interface, a new generation of scaffolds has been designed to improve continuity between these distinct tissue layers. Material gradients can be incorporated in a number of ways, by means of composition, mechanical stiffness, and distribution of bioactive molecules.

Mohan et al. adjusted the flow rates of PLGA microspheres encapsulating either TGF- $\beta 1$ or BMP-2/HA as they were transferred into a cylindrical mold prior to sintering, yielding a scaffold consisting of chondrogenic particles in the top region, followed by a transitionally linear mixture of chondrogenic and osteogenic particles leading to a bottom layer of osteogenic particles. ${ }^{59} 12$ weeks after implantation in the rabbit femoral condyle, this material received the best histological scores for amount and distribution of GAG, cartilage thickness, bone mineralization, and integration with native tissue around the osteochondral defect site. Work by Dormer et al. also examined the effects of a bioactive factor gradient using PLGA microspheres. ${ }^{16}$ By porogen leaching PLGA with gelatin microparticles of various diameter ranges, Tang et al. prepared a scaffold consisting of graded pores: 80 $200 \mu \mathrm{m}$ (top), $200-350 \mu \mathrm{m}$ (middle), and 350-450 $\mu \mathrm{m}$ (bottom). ${ }^{83}$ Osteoblasts on all three layers were able to proliferate and showed an affinity for the smaller pores, yet did not demonstrate enhanced capacity for differentiation in the 14 days of in vitro study. Likewise, Nukavarapu and coworkers also examined the effects of pore size in PLGA microparticlebased scaffolds. ${ }^{62}$

In a pilot study, Kon et al. surgically implanted a commercially available trilayered type I collagen scaffold that varied in HA content: none (cartilage layer), $40 \%$ (interface), and 70\% (subchondral bone layer) into different types of osteochondral defects in human subjects. ${ }^{46}$ A two-year post-operative follow-up showed that the scaffold could promote cartilage and bone regeneration, evidenced by clinical observations and magnetic resonance imaging (MRI) scans. ${ }^{46}$ This study should be expanded in the future to better evaluate the results.

The development of 3D bioprinting presents an attractive option for achieving desirable size features and spatial organization for recreating the zonal layers of cartilage. Cui et al. deposited layer-by-layer a solution of human articular chondrocytes and poly(ethylene glycol)-dimethacrylate (PEGDMA) into osteochondral plug defects. ${ }^{14}$ After six weeks of in vitro culture, the cells exhibited higher collagen II and aggrecan expression and lower collagen I expression than their non-bioprinted counterparts. Furthermore, increased GAG content was also observed, as well as improved neocartilage integration with native tissue. Salerno et al. utilized a novel carbon dioxide foaming technique that relies on pressure rather than organic solvents to generate PCL scaffolds containing bioactive HA nanocrystals as well as sodium chloride porogens to ensure interconnectivity within the material. ${ }^{72}$

Subsequent characterization suggested that the resulting gradient of porosity and pore sizes might be appropriate for osteochondral applications and merits further investigation. 
Design Considerations-A summary of osteochondral tissue engineering scaffold types is shown in Table 2. As with bone tissue engineering, material choice and fabrication strategy greatly influence the result of cartilage formation. The zonal architecture of articular cartilage also contains distinct gradients of ECM components and mechanical properties that will need to be recapitulated in a scaffold. ${ }^{60}$ Regarding porosity, interconnected pore sizes should be smaller than that of subchondral bone because of differences in nutrient derivation: cartilage from tissue fluid and bone from the blood supply. ${ }^{23}$ Another crucial design factor involves engineering the osteochondral interface, where the two contrasting tissues of cartilage and bone meet. This often relies on a multilayer scaffold approach with different material compositions defining each tissue and the boundary between them. If generated separately, these layers must be carefully laminated together with a bonding agent such as fibrin glue. ${ }^{61}$ Hence, more recent attention has been given to leveraging current technology for designing scaffolds with better continuity.

\section{Conclusions}

Summarily, biomaterial design for bone and cartilage tissue engineering has made great strides in the past decades and holds tremendous impact for future clinical applications. Continued growth of this field hinges in part on the development of new materials and improved scaffold processing techniques. Moreover, a deeper comprehension of the underlying mechanisms of bone and cartilage formation would contribute invaluably to tailoring scaffold properties in a manner more representative of the native environment. Currently, the focus has been on addressing biomimetic surface topography for influencing cell behavior, controlled delivery of bioactive signals to stimulate regeneration, bone construct vascularization, articular cartilage zonal architecture, and osteochondral interface integration. Recent advances in the field of biomaterials suggest a promising future for their application in bone and cartilage tissue engineering.

\section{Acknowledgments}

Research towards the development of biomaterials for tissue engineering applications has been supported by the National Institutes of Health (R01 AR048756, R01 AR057083 and R01 DE017441) and the Armed Forces Institute of Regenerative Medicine (W81XWH-08-2-0032). EJL acknowledges support by a National Science Foundation Graduate Research Fellowship.

\section{Abbreviations}

$\begin{array}{ll}\text { ALP } & \text { alkaline phosphatase } \\ \text { ASP } & \text { aspartic acid } \\ \text { BCP } & \text { biphasic calcium phosphate } \\ \text { BG } & \text { bioactive glass } \\ \text { BG1 } & \text { bioactive glass of composition } \mathrm{Na}_{2} \mathrm{O}-\mathrm{K} 2 \mathrm{O}-\mathrm{MgO}-\mathrm{CaO}-\mathrm{B}_{2} \mathrm{O}_{3}-\mathrm{P}_{2} \mathrm{O}_{5}-\mathrm{SiO}_{2} \\ \text { BMP } & \text { bone morphogenetic protein } \\ \text { BSP } & \text { bone sialoprotein } \\ \text { CaP } & \text { calcium phosphate } \\ \text { CNSFs } & \text { chitosan nanofibers } \\ \text { Col I } & \text { collagen I } \\ \text { CSD } & \text { critical size defect }\end{array}$




\begin{tabular}{|c|c|}
\hline CS-MA & chondroitin sulfate-methacrylate \\
\hline ECM & extracellular matrix \\
\hline ECs & endothelial cells \\
\hline FDA & Food and Drug Administration \\
\hline GAG & glycosaminoglycan \\
\hline HA & hydroxyapatite \\
\hline HAc & hyaluronic acid \\
\hline HIF & hypoxia-inducible factor \\
\hline hMSCs & human mesenchymal stem cells \\
\hline $\mathbf{I L}$ & interleukin \\
\hline Mg & magnesium \\
\hline MAPK/ERK & mitogen-activated protein kinase/extracellular signal-regulated kinase \\
\hline mMSCs & mouse mesenchymal stem cells \\
\hline MRI & magnetic resonance imaging \\
\hline PA & peptide amphiphile \\
\hline PCL & poly( $\varepsilon$-caprolactone $)$ \\
\hline pDNA & plasmid DNA \\
\hline PECE & PEG-PCL-PEG copolymer \\
\hline PEG & poly(ethylene glycol) \\
\hline PEGDMA & poly(ethylene glycol)-dimethacrylate \\
\hline PGA & $\operatorname{poly}($ glycolic acid $)$ \\
\hline PHEMA & poly(2-hydroxyethyl methacrylate) \\
\hline PLGA & poly(lactic-co-glycolic acid) \\
\hline PMMA & polymethylmethacrylate \\
\hline PPC & poly(propylene carbonate) \\
\hline PPF & poly(propylene fumarate) \\
\hline PVA-MA & poly(vinyl alcohol)-methacrylate \\
\hline RGD & arginine-glycine-aspartic acid \\
\hline rhBMP-2 & recombinant human bone morphogenetic protein- 2 \\
\hline rMSCs & rabbit mesenchymal stem cells \\
\hline Runx2 & runt-related transcription factor 2 \\
\hline SBF & simulated body fluid \\
\hline Ta & tantalum \\
\hline TBDC & teicoplanin-loaded borate bioactive glass \\
\hline $\mathbf{T C P}$ & tricalcium phosphate \\
\hline TGF & transforming growth factor \\
\hline
\end{tabular}


Ti titanium

TNF tumor necrosis factor

US-SWNTs ultra-short single-walled carbon nanotubes

VEGF vascular endothelial growth factor

\section{References}

1. Amosi N, Zarzhitsky S, Gilsohn E, Salnikov O, Monsonego-Ornan E, Shahar R, Rapaport H. Acidic peptide hydrogel scaffolds enhance calcium phosphate mineral turnover into bone tissue. Acta Biomater. 2012; 8:2466-2475. [PubMed: 22503952]

2. Bal BS, Rahaman MN, Jayabalan P, Kuroki K, Cockrell MK, Yao JQ, Cook JL. In vivo outcomes of tissue-engineered osteochondral grafts. J Biomed Mater Res, Part B. 2010; 93:164-174.

3. Balla VK, Bodhak S, Bose S, Bandyopadhyay A. Porous tantalum structures for bone implants: Fabrication, mechanical and in vitro biological properties. Acta Biomater. 2010; 6:3349-3359. [PubMed: 20132912]

4. Bandyopadhyay A, Espana F, Balla VK, Bose S, Ohgami Y, Davies NM. Influence of porosity on mechanical properties and in vivo response of ti6al4v implants. Acta Biomater. 2010; 6:1640-1648. [PubMed: 19913643]

5. Bhosale AM, Richardson JB. Articular cartilage: Structure, injuries and review of management. $\mathrm{Br}$ Med Bull. 2008; 87:77-95. [PubMed: 18676397]

6. Buckwalter, JA.; Rosenberg, LC.; Hunziker, EB. Articular cartilage: Composition, structure, response to injury, and methods of facilitating repair. In: Ewing, J., editor. Articular Cartilage and Knee Joint Function: Basic Science and Arthroscopy. New York: Raven Press; 1990. p. 19-56.

7. Buckwalter JA, Mankin HJ, Grodzinsky AJ. Articular cartilage and osteoarthritis. Instr Course Lect. 2005; 54:465-480. [PubMed: 15952258]

8. Buckwalter JA, Glimcher MJ, Cooper RR, Recker R. Bone biology. J Bone Joint Surg Am. 1995; 77:1256-1275.

9. Cancedda R, Dozin B, Giannoni P, Quarto R. Tissue engineering and cell therapy of cartilage and bone. Matrix Biol. 2003; 22:81-91. [PubMed: 12714045]

10. Chen J, Chen H, Li P, Diao H, Zhu S, Dong L, Wang R, Guo T, Zhao J, Zhang J. Simultaneous regeneration of articular cartilage and subchondral bone in vivo using mscs induced by a spatially controlled gene delivery system in bilayered integrated scaffolds. Biomaterials. 2011; 32:47934805. [PubMed: 21489619]

11. Coburn JM, Gibson M, Monagle S, Patterson Z, Elisseeff JH. Bioinspired nanofibers support chondrogenesis for articular cartilage repair. Proc Natl Acad Sci USA. 2012; 109:10012-10017. [PubMed: 22665791]

12. Cohen MM Jr. The new bone biology: Pathologic, molecular, and clinical correlates. Am J Med Genet A. 2006; 140:2646-2706. [PubMed: 17103447]

13. Cohen NP, Foster RJ, Mow VC. Composition and dynamics of articular cartilage: Structure, function, and maintaining healthy state. J Orthop Sports Phys Ther. 1998; 28:203-215. [PubMed: 9785256]

14. Cui X, Breitenkamp K, Finn MG, Lotz M, D'lima DD. Direct human cartilage repair using threedimensional bioprinting technology. Tissue Eng Pt A. 2012; 18:1304-1312.

15. Das K V, Balla K, Bandyopadhyay A, Bose S. Surface modification of laser-processed porous titanium for load-bearing implants. Scripta Mater. 2008; 59:822-825.

16. Dormer NH, Singh M, Wang L, Berkland CJ, Detamore MS. Osteochondral interface tissue engineering using macroscopic gradients of bioactive signals. Ann Biomed Eng. 2010; 38:2167_ 2182. [PubMed: 20379780]

17. Downey PA, Siegel MI. Bone biology and the clinical implications for osteoporosis. Phys Ther. 2006; 86:77-91. [PubMed: 16386064] 
18. Fu S, Ni P, Wang B, Chu B, Zheng L, Luo F, Luo J, Qian Z. Injectable and thermo-sensitive PEGPCL-PEG copolymer/collagen/n-HA hydrogel composite for guided bone regeneration. Biomaterials. 2012; 33:4801-4809. [PubMed: 22463934]

19. Galperin A, Oldinski RA, Florczyk SJ, Bryers JD, Zhang M, Ratner BD. Integrated bi-layered scaffold for osteochondral tissue engineering. Adv Healthcare Mater. 2012

20. Gerhardt LC, Widdows KL, Erol MM, Nandakumar A, Roqan IS, Ansari T, Boccaccini AR. Neocellularization and neovascularization of nanosized bioactive glass-coated decellularized trabecular bone scaffolds. J Biomed Mater Res, Part A. 2012; 101A:827-841.

21. Getgood AMJ, Kew SJ, Brooks R, Aberman H, Simon T, Lynn AK, Rushton N. Evaluation of early-stage osteochondral defect repair using a biphasic scaffold based on a collagenglycosaminoglycan biopolymer in a caprine model. Knee. 2011; 19:422-430. [PubMed: 21620711]

22. Guo H, Su J, Wei J, Kong H, Liu C. Biocompatibility and osteogenicity of degradable ca-deficient hydroxyapatite scaffolds from calcium phosphate cement for bone tissue engineering. Acta Biomater. 2009; 5:268-278. [PubMed: 18722167]

23. Guo X, Wang C, Duan C, Descamps M, Zhao Q, Dong L, Anselme SLüK, Lu J, Song YQ. Repair of osteochondral defects with autologous chondrocytes seeded onto bioceramic scaffold in sheep. Tissue Eng. 2004; 10:1830-1840. [PubMed: 15684691]

24. Hari Reddi A. Regulation of cartilage and bone differentiation by bone morphogenetic proteins. Curr Opin Cell Biol. 1992; 4:850-855. [PubMed: 1419064]

25. Healy KE, Guldberg RE. Bone tissue engineering. J Musculoskelet Neuronal Interact. 2007; 7:328-330. [PubMed: 18094496]

26. Heinegård D, Oldberg A. Structure and biology of cartilage and bone matrix noncollagenous macromolecules. FASEB J. 1989; 3:2042-2051. [PubMed: 2663581]

27. Henslee AM, Gwak DH, Mikos AG, Kasper FK. Development of a biodegradable bone cement for craniofacial applications. J Biomed Mater Res A. 2012; 110A:2252-2259. [PubMed: 22499285]

28. Hertz A I, Bruce J. Inorganic materials for bone repair or replacement applications. Nanomedicine. 2007; 2:899-918. [PubMed: 18095853]

29. Holland TA, Mikos AG. Advances in drug delivery for articular cartilage. J Control Release. 2003; 86:1-14. [PubMed: 12490368]

30. Hollinger JO, Battistone GC. Biodegradable bone repair materials synthetic polymers and ceramics. Clin Orthop Rel Res. 1986; 207:290-306.

31. Holmes RE. Bone regeneration within a coralline hydroxyapatite implant. Plast Reconstr Surg. 1979; 63:626-633. [PubMed: 432330]

32. Huang W, Day DE, Kittiratanapiboon K, Rahaman MN. Kinetics and mechanisms of the conversion of silicate (45S5), borate, and borosilicate glasses to hydroxyapatite in dilute phosphate solutions. J Mater Sci Mater Med. 2006; 17:583-596. [PubMed: 16770542]

33. Hunziker EB. Articular cartilage repair: Are the intrinsic biological constraints undermining this process insuperable? Osteoarthr Cartil. 1999; 7:15-28. [PubMed: 10367012]

34. Hunziker EB. Articular cartilage repair: Basic science and clinical progress. A review of the current status and prospects. Osteoarthr Cartil. 2002; 10:432-463. [PubMed: 12056848]

35. Hutmacher DW. Scaffolds in tissue engineering bone and cartilage. Biomaterials. 2000; 21:25292543. [PubMed: 11071603]

36. Huttenlocker, AK.; Woodward, HN.; Hall, BK. The biology of bone. In: Padian, K.; Lamm, ET., editors. Bone Histology of Fossil Tetrapods: Advancing Methods, Analysis, and Interpretation. University of California Press; 2013. p. 13-34.

37. Jayakumar P, Di Silvio L. Osteoblasts in bone tissue engineering. Proc Inst Mech Eng H J Eng Med. 2010; 224:1415-1440.

38. Jeong CG, Zhang H, Hollister SJ. Three-dimensional polycaprolactone scaffold-conjugated bone morphogenetic protein-2 promotes cartilage regeneration from primary chondrocytes in vitro and in vivo without accelerated endochondral ossification. J Biomed Mater Res, Part A. 2012; 100A: 2088-2096. 
39. Jiang J, Tang A, Ateshian GA, Guo XE, Hung CT, Lu HH. Bioactive stratified polymer ceramichydrogel scaffold for integrative osteochondral repair. Ann Biomed Eng. 2010; 38:2183-2196. [PubMed: 20411332]

40. Jones JR, Ehrenfried LM, Hench LL. Optimising bioactive glass scaffolds for bone tissue engineering. Biomaterials. 2006; 27:964-973. [PubMed: 16102812]

41. Kang Y, Kim S, Bishop J, Khademhosseini A, Yang Y. The osteogenic differentiation of human bone marrow MSCs on HUVEC-derived ECM and $\beta$-TCP scaffold. Biomaterials. 2012; 33:69987007. [PubMed: 22795852]

42. Khanarian NT, Haney NM, Burga RA, Lu HH. A functional agarose-hydroxyapatite scaffold for osteochondral interface regeneration. Biomaterials. 2012; 33:5247-5258. [PubMed: 22531222]

43. Kim HJ I, Park K, Kim JH, Cho CS, Kim MS. Gas foaming fabrication of porous biphasic calcium phosphate for bone regeneration. Tissue Eng Regen Med. 2012; 9:63-68.

44. Kim K, Dean D, Wallace J, Breithaupt R, Mikos AG, Fisher JP. The influence of stereolithographic scaffold architecture and composition on osteogenic signal expression with rat bone marrow stromal cells. Biomaterials. 2011; 32:3750-3763. [PubMed: 21396709]

45. Kolk A, Handschel J, Drescher W, Rothamel D, Kloss F, Blessmann M, Heiland M, Wolff KD, Smeets R. Current trends and future perspectives of bone substitute materials-from space holders to innovative biomaterials. J Cranio Maxill Surg. 2012; 40:706-718.

46. Kon E, Delcogliano M, Filardo G, Busacca M, Di Martino A, Marcacci M. Novel nano-composite multilayered biomaterial for osteochondral regeneration a pilot clinical trial. Am J Sports Med. 2011; 39:1180-1190. [PubMed: 21310939]

47. Lamoureux F, Baud'huin M, Duplomb L, Heymann D, Rédini F. Proteoglycans: Key partners in bone cell biology. BioEssays. 2007; 29:758-771. [PubMed: 17621645]

48. Lanza, RP.; Langer, R.; Vacanti, JP. Principles of tissue engineering. 2. San Diego: Academic Press; 2000.

49. Lee $\mathrm{SH}$, Shin H. Matrices and scaffolds for delivery of bioactive molecules in bone and cartilage tissue engineering. Adv Drug Deliver Rev. 2007; 59:339-359.

50. Levorson EJ, Sreerekha PR, Chennazhi KP, Kasper FK, Nair SV, Mikos AG. Fabrication and characterization of multiscale electrospun scaffolds for cartilage regeneration. Biomed Mater. 2013; 8:014103. [PubMed: 23353096]

51. Li Y, Xiong J, Hodgson PD, Wen C. Effects of structural property and surface modification of Ti6Ta4Sn scaffolds on the response of $\mathrm{SaOS}_{2}$ cells for bone tissue engineering. J Alloy Compd. 2010; 494:323-329.

52. Lin ZY, Duan ZX, Guo XD, Li JF, Lu HW, Zheng QX, Quan DP, Yang SH. Bone induction by biomimetic PLGA-(PEG-ASP) $)_{n}$ copolymer loaded with a novel synthetic bmp-2-related peptide in vitro and in vivo. J Control Release. 2010; 144:190-195. [PubMed: 20184932]

53. Mandal BB, Grinberg A, Seok Gil E, Panilaitis B, Kaplan DL. High-strength silk protein scaffolds for bone repair. Proc Natl Acad Sci USA. 2012; 109:7699-7704. [PubMed: 22552231]

54. Mandelbaum BR, Browne JE, Fu F, Micheli L, Mosely JB, Erggelet C, Minas T, Peterson L. Articular cartilage lesions of the knee. Am J Sports Med. 1998; 26:853-861. [PubMed: 9850792]

55. Marks SC, Popoff SN. Bone cell biology: The regulation of development, structure, and function in the skeleton. Am J Anat. 2005; 183:1-44. [PubMed: 3055928]

56. Mieszawska AJ, Fourligas N, Georgakoudi I, Ouhib NM, Belton DJ, Perry CC, Kaplan DL. Osteoinductive silk-silica composite biomaterials for bone regeneration. Biomaterials. 2010; 31:8902-8910. [PubMed: 20817293]

57. Miguel BS, Kriauciunas R, Tosatti S, Ehrbar M, Ghayor C, Textor M, Weber FE. Enhanced osteoblastic activity and bone regeneration using surface-modified porous bioactive glass scaffolds. J Biomed Mater Res, Part A. 2010; 94:1023-1033.

58. Minatoya T, Furusawa T, Sato M, Matsushima Y, Unuma H. Bioactive glass cloth that promotes new bone formation. Key Eng Mat. 2013; 529:266-269.

59. Mohan N, Dormer NH, Caldwell KL, Key VH, Berkland CJ, Detamore MS. Continuous gradients of material composition and growth factors for effective regeneration of the osteochondral interface. Tissue Eng Pt A. 2011; 17:2845-2855. 
60. Nguyen LH, Kudva AK, Saxena NS, Roy K. Engineering articular cartilage with spatially-varying matrix composition and mechanical properties from a single stem cell population using a multilayered hydrogel. Biomaterials. 2011; 32:6946-6952. [PubMed: 21723599]

61. Nooeaid P, Salih V, Beier JP, Boccaccini AR. Osteochondral tissue engineering: Scaffolds, stem cells and applications. J Cell Mol Med. 2012; 16:2247-2270. [PubMed: 22452848]

62. Nukavarapu SP, Dorcemus DL. Osteochondral tissue engineering: Current strategies and challenges. Biotechnol Adv. 2012 In Press.

63. Ott, SM. New aspects of normal bone biology. In: Olgaard, K.; Silver, J.; Salusky, IB., editors. The Spectrum of Mineral and Bone Disorders in Chronic Kidney Disease. Oxford University Press; 2010. p. 15-28.

64. Panagiotis M. Classification of non-union. Injury. 2005; 36:S30-S37. [PubMed: 16291321]

65. Patel ZS, Young S, Tabata Y, Jansen JA, Wong MEK, Mikos AG. Dual delivery of an angiogenic and an osteogenic growth factor for bone regeneration in a critical size defect model. Bone. 2008; 43:931-940. [PubMed: 18675385]

66. Place ES, Rojo L, Gentleman E, Sardinha JP, Stevens MM. Strontium-and zinc-alginate hydrogels for bone tissue engineering. Tissue Eng Pt A. 2011; 17:2713-2722.

67. Rahaman MN, Day DE, Sonny Bal B, Fu Q, Jung SB, Bonewald LF, Tomsia AP. Bioactive glass in tissue engineering. Acta Biomater. 2011; 7:2355-2373. [PubMed: 21421084]

68. Ratcliffe, A.; Mow, VC. Articular cartilage. In: Comper, WD., editor. Extracellular Matrix: Tissue Function. Amsterdam: Harwood Academic Publishers; 1996. p. 234-302.

69. Re'em T, Witte F, Willbold E, Ruvinov E, Cohen S. Simultaneous regeneration of articular cartilage and subchondral bone induced by spatially-presented TGF-beta and BMP-4 in a bi-layer affinity binding system. Acta Biomater. 2012; 8:3283-3293. [PubMed: 22617742]

70. Recker, RR.; Barger-Lux, J. Embryology, anatomy, and microstructure of bone. In: Coe, FL.; Favus, MJ., editors. Disorders of bone and mineral metabolism. New York: Raven Press; 1992. p. 219-240.

71. Renno ACM, Van De Watering FCJ, Nejadnik MR, Crovace MC, Zanotto ED, Wolke JGC, Jansen JA, Van Den Beucken J. Incorporation of bioactive glass in calcium phosphate cement: In vivo evaluation. Acta Biomater. 2013; 9:5728-5739. [PubMed: 23159565]

72. Salerno A, Iannace S, Netti PA. Graded biomimetic osteochondral scaffold prepared via $\mathrm{CO}_{2}$ foaming and micronized $\mathrm{NaCl}$ leaching. Mater Lett. 2012; 82:137-140.

73. Salgado CL, Sanchez EMS, Zavaglia CaC, Almeida AB, Granja PL. Injectable biodegradable polycaprolactone-sebacic acid gels for bone tissue engineering. Tissue Eng Pt A. 2011; 18:137146.

74. Santos CFL, Silva AP, Lopes L, Pires I, Correia IJ. Design and production of sintered $\beta$-tricalcium phosphate 3D scaffolds for bone tissue regeneration. Mater Sci Eng C. 2012; 32:1293-1298.

75. Schwarz S, Koerber L, Elsaesser AF, Goldberg-Bockhorn E, Seitz AM, Dürselen L, Ignatius A, Walther P, Breiter R, Rotter N. Decellularized cartilage matrix as a novel biomatrix for cartilage tissue-engineering applications. Tissue Eng Pt A. 2012; 18:2195-2209.

76. Shah RN, Shah NA, Lim MMDR, Hsieh C, Nuber G, Stupp SI. Supramolecular design of selfassembling nanofibers for cartilage regeneration. Proc Natl Acad Sci USA. 2010; 107:3293-3298. [PubMed: 20133666]

77. Sheehy EJ, Vinardell T, Buckley CT, Kelly DJ. Engineering osteochondral constructs through spatial regulation of endochondral ossification. Acta Biomater. 2012; 9:5484-5492. [PubMed: 23159563]

78. Simon M, Lagneau C, Moreno J, Lissac M, Dalard F, Grosgogeat B. Corrosion resistance and biocompatibility of a new porous surface for titanium implants. Eur J Oral Sci. 2005; 113:537545. [PubMed: 16324146]

79. Sitharaman B, Shi X, Walboomers XF, Liao H, Cuijpers V, Wilson LJ, Mikos AG, Jansen JA. In vivo biocompatibility of ultra-short single-walled carbon nanotube/biodegradable polymer nanocomposites for bone tissue engineering. Bone. 2008; 43:362-370. [PubMed: 18541467]

80. Sohier J, Daculsi G, Sourice S, De Groot K, Layrolle P. Porous beta tricalcium phosphate scaffolds used as a BMP-2 delivery system for bone tissue engineering. J Biomed Mater Res, Part A. 2010; 92:1105-1114. 
81. Spicer PP, Kretlow JD, Henslee AM, Shi M, Young S, Demian N, Jansen JA, Wong ME, Mikos AG, Kasper FK. In situ formation of porous space maintainers in a composite tissue defect. J Biomed Mater Res, Part A. 2012; 100A:827-833.

82. Takemoto M, Fujibayashi S, Neo M, Suzuki J, Kokubo T, Nakamura T. Mechanical properties and osteoconductivity of porous bioactive titanium. Biomaterials. 2005; 26:6014-6023. [PubMed: 15885769]

83. Tang G, Zhang H, Zhao Y, Zhang Y, Li X, Yuan X. Preparation of PLGA scaffolds with graded pores by using a gelatin-microsphere template as porogen. J Biomat Sci-Polym E. 2012; 23:22412257.

84. Tarafder S, Balla VK, Davies NM, Bandyopadhyay A, Bose S. Microwave-sintered 3D printed tricalcium phosphate scaffolds for bone tissue engineering. J Tissue Eng Regen Med. 2012 Early view.

85. Teixeira S, Fernandes H, Leusink A, Van Blitterswijk C, Ferraz MP, Monteiro FJ, De Boer J. In vivo evaluation of highly macroporous ceramic scaffolds for bone tissue engineering. J Biomed Mater Res, Part A. 2010; 93:567-575.

86. Temenoff JS, Mikos AG. Review: Tissue engineering for regeneration of articular cartilage. Biomaterials. 2000; 21:431-440. [PubMed: 10674807]

87. Ulrich-Vinther M, Maloney MD, Schwarz EM, Rosier R, O’keefe RJ. Articular cartilage biology. J Am Acad Orthop Surg. 2003; 11:421-430. [PubMed: 14686827]

88. Väänänen K. Mechanism of osteoclast mediated bone resorption-rationale for the design of new therapeutics. Adv Drug Deliver Rev. 2005; 57:959-971.

89. Venkatesan J, Ryu B, Sudha PN, Kim SK. Preparation and characterization of chitosan-carbon nanotube scaffolds for bone tissue engineering. Int J Biol Macromol. 2012; 50:393-402. [PubMed: 22234296]

90. Wang L, Stegemann JP. Thermogelling chitosan and collagen composite hydrogels initiated with $\beta$-glycerophosphate for bone tissue engineering. Biomaterials. 2010; 31:3976-3985. [PubMed: 20170955]

91. Willers C, Wood DJ, Zheng MH. A current review on the biology and treatment of articular cartilage defects (part I \& part II). J Musculoskelet Res. 2003; 7:157-181.

92. Witte F, Ulrich H, Palm C, Willbold E. Biodegradable magnesium scaffolds: Part II: Peri-implant bone remodeling. J Biomed Mater Res, Part A. 2007; 81:757-765.

93. Wu C, Miron R, Sculean A, Kaskel S, Doert T, Schulze R, Zhang Y. Proliferation, differentiation and gene expression of osteoblasts in boron-containing associated with dexamethasone deliver from mesoporous bioactive glass scaffolds. Biomaterials. 2011; 32:7068-7078. [PubMed: 21704367]

94. Wu C, Zhou Y, Fan W, Han P, Chang J, Yuen J, Zhang M, Xiao Y. Hypoxia-mimicking mesoporous bioactive glass scaffolds with controllable cobalt ion release for bone tissue engineering. Biomaterials. 2011; 33:2076-2085. [PubMed: 22177618]

95. Xue W, Krishna BV, Bandyopadhyay A, Bose S. Processing and biocompatibility evaluation of laser processed porous titanium. Acta Biomater. 2007; 3:1007-1018. [PubMed: 17627910]

96. Yang W, Yang F, Wang Y, Both SK, Jansen JA. In vivo bone generation via the endochondral pathway on three-dimensional electrospun fibers. Acta Biomater. 2013; 9:4505-4512. [PubMed: 23059416]

97. Yaszemski, MJ.; Yasko, AW. Musculoskeletal tissue engineering for orthopedic surgical applications. In: Patrick, CW.; Mikos, AG.; McIntire, LV., editors. Frontiers in Tissue Engineering. Elsevier; 1998. p. 197-212.

98. Young S, Patel ZS, Kretlow JD, Murphy MB, Mountziaris PM, Baggett LS, Ueda H, Tabata Y, Jansen JA, Wong M. Dose effect of dual delivery of vascular endothelial growth factor and bone morphogenetic protein-2 on bone regeneration in a rat critical-size defect model. Tissue Eng Pt A. 2009; 15:2347-2362.

99. Yu HS, Jin GZ, Won JE, Wall I, Kim HW. Macrochanneled bioactive ceramic scaffolds in combination with collagen hydrogel: A new tool for bone tissue engineering. J Biomed Mater Res, Part A. 2012; 100A:2431-2440. 
100. Yuan H, Fernandes H, Habibovic P, De Boer J, Barradas AMC, De Ruiter A, Walsh WR, Van Blitterswijk CA, De Bruijn JD. Osteoinductive ceramics as a synthetic alternative to autologous bone grafting. Proc Natl Acad Sci USA. 2010; 107:13614-13619. [PubMed: 20643969]

101. Zhang X, Jia WT, Gu YF, Xiao W, Liu X, Wang DP, Zhang CQ, Huang WH, Rahaman MN, Day DE. Teicoplanin-loaded borate bioactive glass implants for treating chronic bone infection in a rabbit tibia osteomyelitis model. Biomaterials. 2010; 31:5865-5874. [PubMed: 20434766]

102. Zhao J, Han W, Chen H, Tu M, Huan S, Miao G, Zeng R, Wu H, Cha Z, Zhou C. Fabrication and in vivo osteogenesis of biomimetic poly (propylene carbonate) scaffold with nanofibrous chitosan network in macropores for bone tissue engineering. J Mater Sci: Mater Med. 2012; 23:517-525. [PubMed: 22042464]

103. Zhou J, Lin H, Fang T, Li X, Dai W, Uemura T, Dong J. The repair of large segmental bone defects in the rabbit with vascularized tissue engineered bone. Biomaterials. 2010; 31:11711179. [PubMed: 19880177]

104. Zhou J, Xu C, Wu G, Cao X, Zhang L, Zhai Z, Zheng Z, Chen X, Wang Y. In vitro generation of osteochondral differentiation of human marrow mesenchymal stem cells in novel collagenhydroxyapatite layered scaffolds. Acta Biomater. 2011; 7:3999-4006. [PubMed: 21757035] 
Table 1

Selected biomaterials for in vivo bone tissue engineering applications.

\begin{tabular}{|c|c|c|c|c|}
\hline Material & Cell Type & Animal Model & Key Findings & Reference \\
\hline \multicolumn{5}{|l|}{ CaP Ceramics } \\
\hline Porous calcium deficient HA & rMSCs & Rabbit mandibular CSD & $\begin{array}{c}\text { Accelerated bone } \\
\text { regeneration for } 2 \text { to } 4 \\
\text { weeks compared to } \\
\text { acellular calcium deficient } \\
\text { HA, complete defect filling } \\
\text { by } 8 \text { weeks }\end{array}$ & [22] \\
\hline Porous $\beta$-TCP & rMSCs, rMSC-derived ECs & Rabbit segmental defect & $\begin{array}{l}\text { Co-culture enhanced both } \\
\text { local vascularization and } \\
\text { osteogenesis }\end{array}$ & [103] \\
\hline Porous BCP (60:40 HA: $\beta-\mathrm{TCP})$ & - & $\begin{array}{c}\text { Rat lower jawbone and } \\
\text { tibia }\end{array}$ & $\begin{array}{l}\text { Vascularization and } \\
\text { immature bone formation } \\
\text { after three weeks, marrow } \\
\text { present in scaffold interior }\end{array}$ & [43] \\
\hline \multicolumn{5}{|l|}{ Bioactive Glasses } \\
\hline SBF-treated BG1 glass fibers & - & Rabbit calvarial non-CSD & $\begin{array}{c}\text { Significantly greater bone } \\
\text { deposition after } 4 \text { weeks } \\
\text { compared to non-SBF } \\
\text { treated BG1 and } \\
\text { commercially available } \\
\text { Perioglass }{ }^{\circledR}\end{array}$ & [57] \\
\hline SBF-treated woven BG-cloth & - & Rat tibial defect & $\begin{array}{c}\text { Bone formation after } 2 \\
\text { weeks, whereas control E- } \\
\text { cloth resulted in } \\
\text { pseudomonas aeruginosa } \\
\text { infection and fibrous tissue }\end{array}$ & [58] \\
\hline TBDC pellets & - & Rabbit tibia osteomyelitis & $\begin{array}{l}\text { Extended antibiotic release } \\
\text { over } 9 \text { days, pellet } \\
\text { degradation and conversion } \\
\text { into osteoconductive HA- } \\
\text { like product stopped } \\
\text { infection and promoted } \\
\text { bone formation by } 12 \\
\text { weeks }\end{array}$ & [101] \\
\hline \multicolumn{5}{|l|}{ Metals } \\
\hline Porous Ti alloy Ti6Al4V & - & Rat femoral defect & $\begin{array}{c}\text { Implants with } 25 \% \\
\text { porosity had higher } \mathrm{Ca}^{2+} \\
\text { concentration and stronger } \\
\text { bonding to native bone } \\
\text { than implants with } 10.7 \% \\
\text { and } 2.8 \% \text { porosity after } 16 \\
\text { weeks }\end{array}$ & [4] \\
\hline Porous Mg alloy AZ91D & - & Rabbit patellar defect & $\begin{array}{l}\text { Scaffold degradation by } 3 \\
\text { months, greater bone } \\
\text { volume and structural } \\
\text { maturity compared to } \\
\text { autologous bone graft at } 3 \\
\text { and } 6 \text { months }\end{array}$ & [92] \\
\hline \multicolumn{5}{|l|}{ Polymers } \\
\hline PMMA & - & Rabbit mandibular defect & $\begin{array}{l}\text { Porous implants promoted } \\
\text { healing of soft tissue but } \\
\text { insufficient sample size for } \\
\text { comparison to their solid } \\
\text { counterparts }\end{array}$ & [81] \\
\hline PLGA/PCL microfibers & $\begin{array}{c}\text { Rat } \\
\text { MSCs }\end{array}$ & Rat subcutaneous pocket & $\begin{array}{l}\text { Significant bone formation } \\
\text { in cell-seeded scaffold } \\
\text { compared to RBMC }\end{array}$ & [96] \\
\hline
\end{tabular}




\begin{tabular}{|c|c|c|c|c|}
\hline Material & Cell Type & Animal Model & Key Findings & Reference \\
\hline & & & $\begin{array}{c}\text { pellets, scaffold not } \\
\text { completely degraded after } \\
8 \text { weeks }\end{array}$ & \\
\hline $\mathrm{PPC} / \mathrm{CNSFs}$ & rMSCs & Rabbit femoral defect & $\begin{array}{l}\text { Nearly complete bone } \\
\text { filling after } 16 \text { weeks, } \\
\text { accelerated osteogenesis } \\
\text { compared to PPC alone }\end{array}$ & [102] \\
\hline \multicolumn{5}{|l|}{ Composites } \\
\hline PECE/Collagen/nano-HA hydrogel & - & Rabbit calvarial defect & $\begin{array}{l}\text { Significant formation of } \\
\text { cortical bone after } 20 \\
\text { weeks compared to control }\end{array}$ & [18] \\
\hline $\mathrm{P}_{\mathrm{FD}}-5$ hydrogel with $\beta$-TCP & - & Rat femoral defect & $\begin{array}{c}\text { Better healing and } \\
\text { integration with native } \\
\text { bone compared to controls } \\
\text { after } 6 \text { weeks, peptide } \\
\text { hydrogel increased rate of } \\
\beta \text {-TCP conversion into } \\
\text { bone mineral }\end{array}$ & [1] \\
\hline $\begin{array}{l}\text { Nano-sized BG-coated } \\
\text { decellularized trabecular bone }\end{array}$ & - & Rat subcutaneous pocket & $\begin{array}{l}\text { Good host cell infiltration } \\
\text { and mature vessel } \\
\text { formation over } 8 \text { weeks in } \\
\text { both nBGcoated and } \\
\text { uncoated scaffolds though } \\
\text { no significant difference }\end{array}$ & [20] \\
\hline US-SWNTs/PPF & - & $\begin{array}{l}\text { Rabbit femoral condyle } \\
\text { defect }\end{array}$ & $\begin{array}{c}\text { Greater bone ingrowth, } \\
\text { fewer inflammatory cells, } \\
\text { and appreciable } \\
\text { organization of connective } \\
\text { tissue compared to controls } \\
\text { after } 12 \text { weeks }\end{array}$ & [79] \\
\hline
\end{tabular}




\begin{tabular}{|c|c|c|c|c|c|c|c|c|c|c|c|}
\hline & 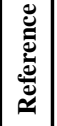 & 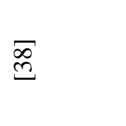 & $\Xi$ & $\stackrel{2}{2}$ & $E$ & \begin{tabular}{|l}
$\bar{\varrho}$ \\
\end{tabular} & $\bar{\varrho}$ & $\Phi$ & $\bar{\Xi}$ & \begin{tabular}{|l}
$\overline{2}$ \\
$\underline{6}$
\end{tabular} & $\underline{\tilde{\infty}}$ \\
\hline & 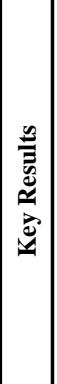 & 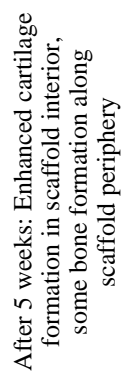 & 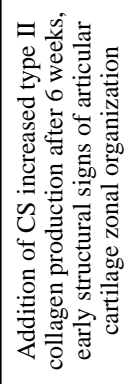 & 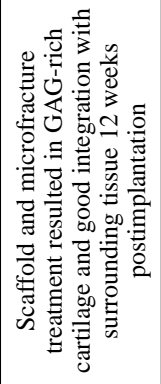 & 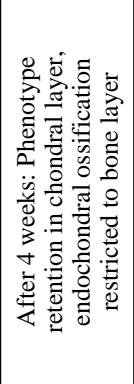 & 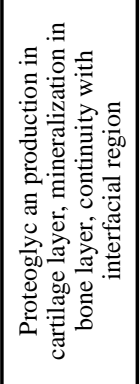 & 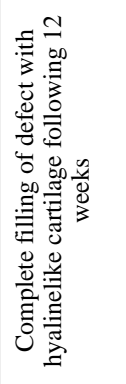 & 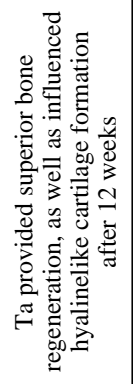 & 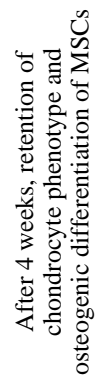 & 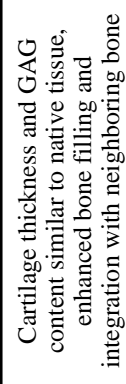 & 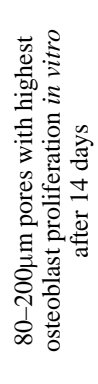 \\
\hline & 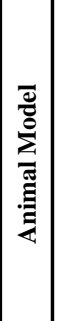 & 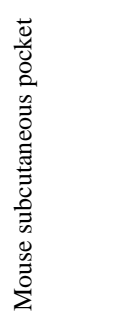 & 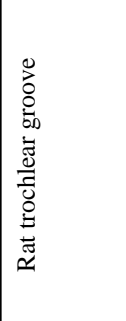 & 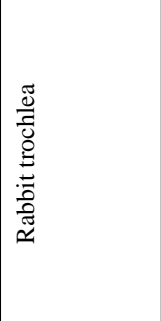 & 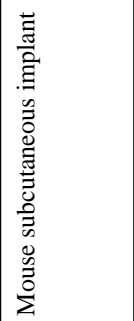 & ' & 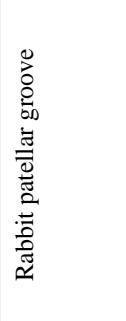 & 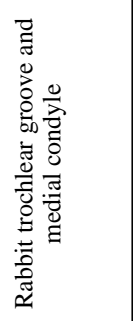 & & 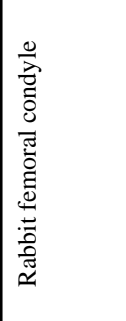 & \\
\hline & 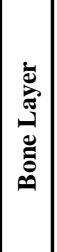 & ' & ' & ' & 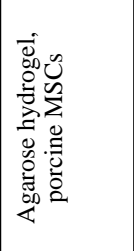 & 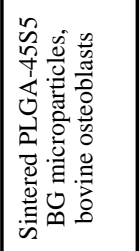 & 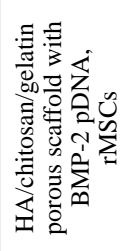 & 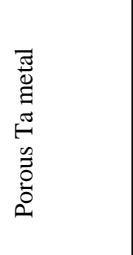 & 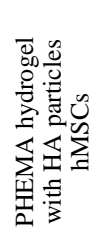 & 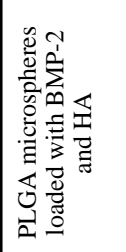 & 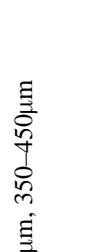 \\
\hline 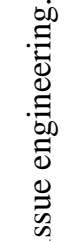 & 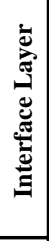 & ' & I & I & I & 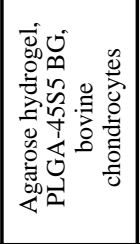 & ' & ' & ' & ' & 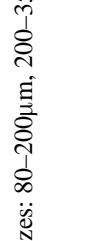 \\
\hline 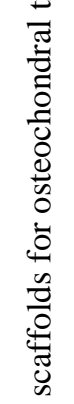 & 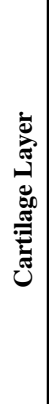 & 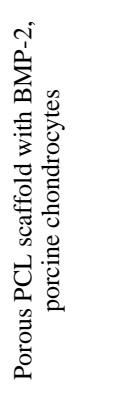 & 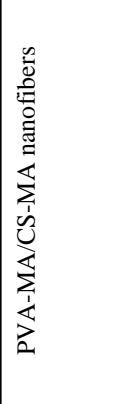 & 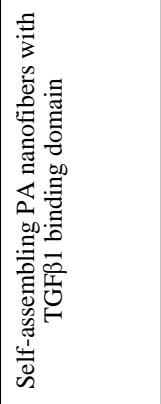 & 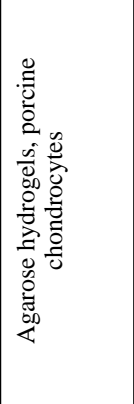 & 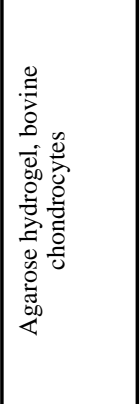 & 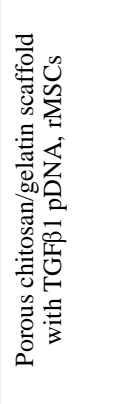 & 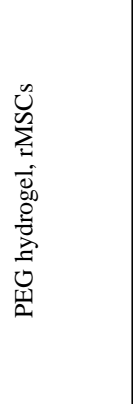 & 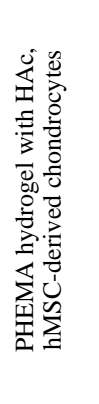 & 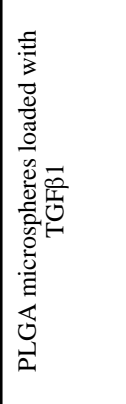 & 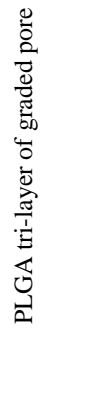 \\
\hline 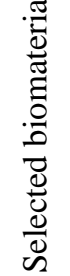 & 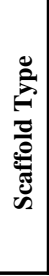 & 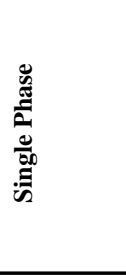 & & & & 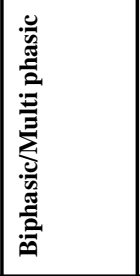 & & & & 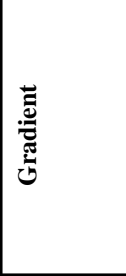 & \\
\hline
\end{tabular}




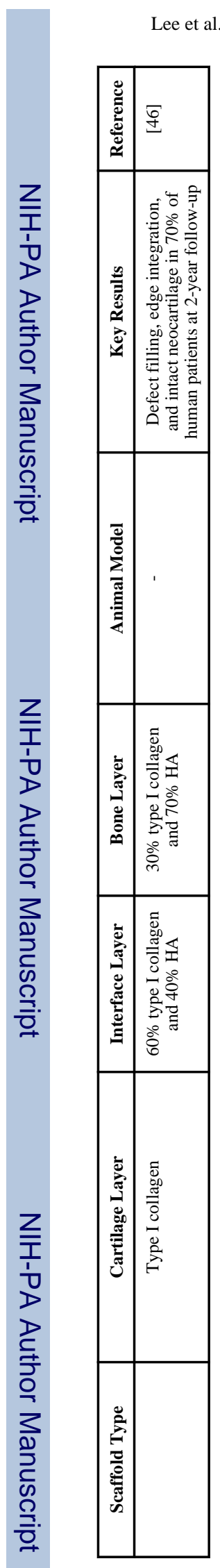

Page 22 